(RESEARCH ARTICLE)

\title{
Comparative assessment of organic and non-organic - chickpea and cowpea, nutritional composition and antinutrients upon germination
}

\author{
Rajesh Devisetti * and Jamuna Prakash \\ Department of Food Science and Nutrition, University of Mysore, Mysore 570006.
}

Publication history: Received on 13 November 2020; revised on 21 November 2020; accepted on 23 November 2020

Article DOI: https://doi.org/10.30574/wjarr.2020.8.2.0432

\begin{abstract}
The nutrient, fatty acid, and antinutrient composition of chickpea and cowpea obtained from organic (org) source and subjected to germination were evaluated in comparison with non-organic (n-org) counterpart. Fat content (range, 2.04$5.89 \%$ ) of n-org legumes were higher. Germination significantly reduced the fat content in cowpea, though in chickpea no difference was seen, whereas, for ash and protein, it was vice versa. Dietary fiber content differed significantly between org (22.82 \%) and n-org (20.23\%) chickpea. Mineral contents of org chickpea and n-org cowpea were higher. Germination significantly reduced the mineral content, except for copper and phosphorous. Differences in the fatty acid content of org and n-org samples were observed. Linoleic acid was the predominant fatty acid in chickpea (58.88-62.75 $\%$ ) and cowpea (36.08-40.43 \%). In cowpea, germination significantly decreased the palmitic and $\alpha$-linoleic acid and increased stearic, oleic, and linoleic acids whereas, in chickpea, no differences were seen. The TPUFA content was higher in germinated cowpea, whereas in chickpea it was unchanged. The enzyme activity (phytase, amylase, and protease) increased significantly upon germination and no significant differences between org and n-org legumes were observed. Phytic acid (PA) and saponin content of the org legumes was lower than n-org. Germination significantly reduced the PA content. The molar ratios of PA: minerals significantly improved upon germination indicating a better availability of iron and calcium. Significant differences between org and n-org legumes were observed, but no particular trend was seen to prove that org legumes are better in nutritional quality than n-org legumes.
\end{abstract}

Keywords: Enzyme Activities; Fatty Acid Profile; Phytic Acid; Saponins; Minerals; Oxalic Acid

\section{Introduction}

Legumes are the predominant source of protein in tropical and subtropical regions [1]. India is the largest producer and consumer (22 and 33\% of total production respectively) of legumes in the world [2]. It has always been an integral part of the Indian dietary system contributing valuable nutrients. Legumes not only add diversity to the human diet, but also serve as a cheap protein source in developing countries like India, where the vegetarian population is prevailing [3].

Chickpeas (Cicer arietinum) are one of the oldest and most widely consumed legumes in the world. Chickpea and its flour are being used extensively in food processing in many countries and it is a staple ingredient in South and Southeast Asian cuisines [4]. Cowpea (Vigna unguiculata), also known as black-eyed peas, Southern peas, and crowder peas are an important source of low-cost protein and energy. However, their wide use is limited by the presence of antinutritional factors which may have adverse effects on human or animal nutrition [5]. These antinutrients may include protease inhibitors, tannins, phytic acid, saponins, lectins, and flatus-producing oligosaccharides [6].

The nutritional quality of legumes can be enhanced by processing. It is believed that organically grown foods are superior in nutritional quality. Organic farming is not a recent evolution in agriculture; man has been practicing many

\footnotetext{
* Corresponding author Rajesh Devisetti ,Email:rajeshjrg@gmail.com

Department of Food Science and Nutrition, University of Mysore, Mysore 570006, India.
} 
of the techniques that are used today for thousands of years [7]. Organically produced food is gaining interest throughout the world in response to concerns about conventional agricultural practices, food safety, and human health concerns. Research conducted globally has focused mainly on the effect of organic cultivation on parameters of soil or crop yield [8]. Recently, however, researchers have paid more attention to the assessment of nutrients in organic food.

Germination is one of the simple, inexpensive processing techniques which improves the overall nutritional quality of legumes [9]. However, the effect of germination depends on the legume type and the conditions and duration of the germination process [10]. There are very limited studies comparing organic and non-organic foods and differences in processing. This study aims to compare the differences in nutritional and antinutritional properties between organic and non-organically grown germinated chickpea and cowpea.

\section{Material and methods}

Chickpea (Cicer arietinum, JG-11) and cowpea (Vigna unguiculata, C-512) samples were collected from certified organic (org) and non-organic (n-org) sources from similar growing conditions around Mysuru, India and cleaned from any foreign materials. The fatty acid standards were of analytical grade from Sigma (Sigma-Aldrich, India). All other chemicals and reagents used were of analytical grade.

\subsection{Processing of the samples}

Whole legume grains were divided into two parts, one part was used for germination and the other served as ungerminated control. Control grains were powdered and packed in polyethylene pouches. Briefly for germination, whole grain samples were soaked in distilled water (1:3) for 6 hrs and germinated for 48 hrs at room temperature by occasionally sprinkling the distilled water. At the end of germination, the grains were lyophilised, powdered and packaged in polyethylene (PE) pouches. All the samples were stored below $4^{\circ} \mathrm{C}$ for further analysis.

\subsection{Nutrient composition}

The protein content of the processed samples was analysed by Kjeldahl method and converted into protein by using Nx6.25, Soxhlet method was used to determine the fat content and ash content was determined gravimetrically by using muffle and moisture content was determined by oven drying method by following standard methods of AOAC [11]. The total dietary fiber (TDF) was determined by rapid enzymatic assay [12]. Briefly, the enzymatic hydrolysis was performed by taking $1.0 \mathrm{~g}$ of sample, gelatinizing in the presence of Termamyl (heat-stable $\alpha$-amylase, $100 \mathrm{mg}$, boiled for $15 \mathrm{~min}, \mathrm{pH} 6.0)$, treated with pepsin $\left(100 \mathrm{mg}, 40^{\circ} \mathrm{C}, 60 \mathrm{~min}, \mathrm{pH} 1.5\right)$ and incubating with pancreatin $\left(100 \mathrm{mg}, 40^{\circ} \mathrm{C}\right.$, $60 \mathrm{~min}, \mathrm{pH}$ 6.8). The insoluble dietary fiber (IDF) was recovered by filtration with celite as a filter aid. Then soluble dietary fiber (SDF) was precipitated from the filtrate with four volumes of $95 \%$ ethanol and recovered by filtration. The non-structural polysaccharides (NSP) content was determined as the weight difference using moisture, protein, fat, and ash and total dietary fiber content data. The analytical values were evaluated from the mean of three determinations for each sample.

\subsection{Fatty acid profile of legume samples}

The extracted oil from the Soxhlet method was used for fatty acid profiling of processed samples. The lipids were transmethylated using $0.2 \mathrm{ml}$ methanolic sodium hydroxide ( $2 \mathrm{M}$ ) followed by $2 \mathrm{M}$ methanolic hydrochloric acid ( $0.2 \mathrm{ml})$ to obtain fatty acid methyl esters (FAME) residues. The gas chromatography (GC) method was followed for fatty acid profiling [13]. Briefly, FAME residues were dissolved in hexane, and precaution was taken to maintain concentrations of FAME. The analysis was carried out by GC (PerkinElmer Clarus 580, USA). A $1.0 \mu$ l of FAME was analysed using Omegawax $^{\mathrm{TM}} 320$ fused silica capillary column $(30 \mathrm{~m} \times 0.32 \mathrm{~mm}$ ID $\times 0.25 \mu \mathrm{m}$ film thickness $)$ with nitrogen as a carrier gas. The conditions used for GC analysis were; injection temperature of $250^{\circ} \mathrm{C}$, flame ionization detector (FID) temperature of $260^{\circ} \mathrm{C}$ and column temperature of $240^{\circ} \mathrm{C}$. The peaks were identified by comparing the retention time with authentic standards. The unknown FAME peak areas were computed, and the relative percentage of individual fatty acid was calculated. The data is presented as the mean of three analyses.

\subsection{Enzyme activities}

Phytase activity was measured by using the method of Egli et al. [14]. Briefly, $1.0 \mathrm{~g}$ of sample was added to $20 \mathrm{ml} 0.1 \mathrm{M}$ Tris-acetate buffer pH 5.0 containing $7.5 \mathrm{mM}$ phytic acid. The $0.5 \mathrm{ml}$ aliquots were taken every $20 \mathrm{~min}$ for $1 \mathrm{~h}$ at $45^{\circ} \mathrm{C}$ under constant stirring and the reaction was terminated by adding $0.5 \mathrm{ml} 0.9 \mathrm{M}$ trichloroacetic acid (TCA). Inorganic phosphate (Pi) was determined colorimetrically [15]. Phytase activity was calculated by linear regression of the Pi determined for each time point. Phytase activity is expressed in phytase units (PU) per g of grains or seeds. One PU is equivalent to the enzymatic activity that liberates $1.0 \mu \mathrm{mol}$ Pi per min. 
Amylase activity was tested according to Bernfeld [16]. A $1 \%$ starch solution in sodium acetate buffer (50mM, pH 4.8) was incubated with appropriate aliquots of the enzyme extracts at $37^{\circ} \mathrm{C}$ for $30 \mathrm{~min}$. the reaction was terminated by adding 3,5-dinitrosalicylic acid reagent and read at $540 \mathrm{~nm}$. Reducing sugars were calculated from a standard curve of maltose. One unit of enzyme activity was defined as a micromole of maltose equivalent released per min under the assay conditions.

The protease activity of the samples was analysed by the method of Müntz [17]. Briefly, $0.5 \mathrm{ml}$ of $1 \%$ casein in distilled water incubated at $37^{\circ} \mathrm{C}$. The reaction was initiated by the addition of $0.1 \mathrm{ml}$ of enzyme extract and stopped by the addition of $1.0 \mathrm{ml}$ of $10 \%$ TCA. The precipitate was removed by filtration, and the quantity of released peptides and amino acids was determined by the Lowry method. Appropriate blanks were maintained and, the specific enzyme activity was defined as units per milligram of protein where $1 \mathrm{U}$ of enzyme activity liberates $1 \mathrm{mg}$ of protein equivalents per h.

\subsection{Anti-nutrients}

Phytic acid (PA) contents of defatted legume flours were determined by the method of Haug and Lantzsch [18]. The phytic acid content was calculated from a calibration curve using phytate phosphorus salt. Total saponin (triterpenoid and steroidal) content was determined using a spectrophotometric method [19]. Sample (0.5 g) was extracted with 80 $\%$ aqueous methanol, and the results were expressed as mg diosgenin equivalent/g using diosgenin in $80 \%$ aqueous methanol as standard. Oxalic acid was estimated by the titration method as described by Agbaire and Emoyan [20]. A $1.0 \mathrm{~g}$ of sample was weighed into $100 \mathrm{ml}$ conical flask, $75 \mathrm{ml} 3 \mathrm{M} \mathrm{H}_{2} \mathrm{SO}_{4}$ was added and stirred for $1 \mathrm{~h}$ with a magnetic stirrer. This was filtered using a Whatman No 1 filter paper. A $25 \mathrm{ml}$ of the filtrate was then taken and titrated while hot against $0.05 \mathrm{M} \mathrm{KMnO}_{4}$ solution until a faint pink colour persisted for at least $30 \mathrm{~s}$. The oxalate content was then calculated by taking $1 \mathrm{ml}$ of $0.05 \mathrm{M} \mathrm{KMnO}_{4}$ as equivalent to $2.2 \mathrm{mg}$ oxalate.

\subsection{Statistical analysis}

All measurements were carried out in triplicate. Data obtained were analysed using a t-test at $\mathrm{p}<0.05$. All statistical analyses were performed using statistical software Statistica'99 (StatSoft, Tulsa, OK, USA).

\section{Results and discussion}

\subsection{Nutrient composition}

The nutrient composition of legume samples is presented in Table 1. The moisture content of the legumes was in the range of 5.45-8.4\%. The fat content of org and n-org chickpea control (5.55-5.89\%) and cowpea (2.04-2.14\%) exhibited significant differences; upon germination, it decreased for cowpea (1.66, and 1.53\%) and showed an insignificant increase for chickpea. The n-org control chickpea fat content was higher when compared with the study of Uppal and Bains [21] while in the case of cowpea the results were comparable. Higher fat in chickpea flour improves the capacity of flour to absorb and retain oil, improves binding of the structure, enhances flavour retention, improves mouthfeel, and reduces moisture and fat losses in food products [22]. Ash content of chickpea and cowpea exhibited variations between org and n-org samples. A decrease in ash content was observed upon germination in org and n-org chickpea whereas it did not differ for cowpea. Ash content values of n-org control chickpea were in agreement whereas cowpea ash content was higher when compared with an earlier report [21].

The protein content of chickpea did not differ significantly between org and n-org samples whereas cowpea exhibited significant differences. Germination increased protein content significantly for all samples. The protein content of $\mathrm{n}$-org control chickpea was lower when compared with the literature values, this may be due to the varietal differences between the samples, whereas cowpea protein content was comparable. A similar increase in protein content during germination was also observed by Uppal and Bains [21]. The protein quality of chickpea and cowpea are very high, as it contains greater amounts of essential amino acids, the essential and non-essential amino acid ratios are 0.99 and 1.03 respectively, which provide a cheap and concentrated source of proteins with essential amino acids [23]. Germination improves the nutritional quality of protein by breaking down into simpler units with protease activity [9].

TDF content differed significantly between org (22.92\%) and n-org (20.23\%) control and germinated chickpea whereas, in cowpea, no differences were seen. IDF content significantly reduced upon germination for org and n-org cowpea, though, in case of chickpea an increase in fiber content was observed. Germination brought significant changes in SDF content with an increase. Dietary fiber helps in decreasing intestinal transit time, maintenance of rich and diverse gut microbes, lowering of blood total cholesterol levels, and reduction in post-prandial blood glucose levels [24]. The results of the n-org control chickpea TDF content are in agreement with the earlier report of Longvah et al. [25], cowpea TDF 
was found to be higher when compared, and this may be due to the varietal differences between the samples. The nonstructural polysaccharides content of the legumes ranged from 46.48-53.98\%, significant differences between org and n-org legumes were not observed for cowpea whereas in chickpea differences were observed. The NSP content of n-org control chickpea was high. Starch, a major constituent of available carbohydrates in legumes, is known to possess low digestibility. This may be ascribed to chain length and amount of amylose present [26].

Table 1 Nutrient composition of control and germinated chickpea and cowpea from organic and non-organic sources (Dry weight basis)

\begin{tabular}{|c|c|c|c|c|c|c|c|}
\hline Parameter & Sample & $\begin{array}{l}\text { Organic } \\
\text { Chickpea }\end{array}$ & $\mathbf{N}$ & $\begin{array}{l}\text { Non-organic } \\
\text { Chickpea }\end{array}$ & $\begin{array}{l}\text { Organic } \\
\text { Cowpea } \\
\end{array}$ & $\mathbf{N}$ & $\begin{array}{l}\text { Non-organic } \\
\text { Cowpea }\end{array}$ \\
\hline \multirow{2}{*}{ Moisture (\%) } & Con. & $5.45 \pm 0.02 *$ & $*$ & $6.51 \pm 0.37^{*}$ & $7.71 \pm 0.13^{*}$ & $*$ & $6.97 \pm 0.34 *$ \\
\hline & Germ. & $8.4 \pm 0.0$ & $*$ & $7.65 \pm 0.04$ & $6.53 \pm 0.02$ & $*$ & $7.25 \pm 0.44$ \\
\hline \multirow[t]{2}{*}{ Fat $(\%)$} & Con. & $5.55 \pm 0.01^{\mathrm{ns}}$ & $*$ & $5.89 \pm 0.21^{\mathrm{ns}}$ & $2.04 \pm 0.04 *$ & $*$ & $2.14 \pm 0.03^{*}$ \\
\hline & Germ. & $5.71 \pm 0.2$ & $*$ & $6.27 \pm 0.15$ & $1.66 \pm 0.02$ & $*$ & $1.53 \pm 0.03$ \\
\hline \multirow[t]{2}{*}{ Ash (\%) } & Con. & $3.19 \pm 0.03^{*}$ & $*$ & $2.74 \pm 0.00^{*}$ & $4.10 \pm 0.04^{\mathrm{ns}}$ & $*$ & $4.21 \pm 0.03^{\mathrm{ns}}$ \\
\hline & Germ. & $2.97 \pm 0.05$ & $*$ & $2.51 \pm 0.04$ & $4.34 \pm 0.3$ & ns & $4.27 \pm 0.04$ \\
\hline \multirow{2}{*}{ Protein (\%) } & Con. & $17.67 \pm 0.1^{*}$ & ns & $17.16 \pm 0.2^{*}$ & $23.92 \pm 0.08^{*}$ & $*$ & $24.45 \pm 0.08^{*}$ \\
\hline & Germ. & $18.37 \pm 0.4$ & $*$ & $17.62 \pm 0.1$ & $26.19 \pm 0.32$ & ns & $26.27 \pm 0.0$ \\
\hline \multirow{2}{*}{ Dietary fiber (\%) } & Con. & $22.92 \pm 1.9^{*}$ & $*$ & $20.23 \pm 0.4^{*}$ & $21.62 \pm 0.8^{\mathrm{ns}}$ & ns & $21.66 \pm 1.2^{\mathrm{ns}}$ \\
\hline & Germ. & $26.50 \pm 0.9$ & $*$ & $23.58 \pm 0.7$ & $20.50 \pm 0.7$ & ns & $20.47 \pm 0.7$ \\
\hline \multirow{2}{*}{$\begin{array}{l}\text { Insoluble } \\
\text { fiber }\end{array}$} & Con. & $18.47 \pm 1.0^{\mathrm{ns}}$ & $*$ & $14.90 \pm 0.5^{*}$ & $17.80 \pm 0.5^{*}$ & ns & $16.99 \pm 1.0^{*}$ \\
\hline & Germ. & $18.72 \pm 0.8$ & $*$ & $16.35 \pm 0.6$ & $13.18 \pm 0.6$ & ns & $13.73 \pm 0.4$ \\
\hline \multirow{2}{*}{ Soluble dietary fiber } & Con. & $4.36 \pm 0.1^{*}$ & $*$ & $5.33 \pm 0.05^{*}$ & $3.81 \pm 0.2^{*}$ & $*$ & $4.67 \pm 0.3^{*}$ \\
\hline & Germ. & $7.77 \pm 0.1$ & $*$ & $7.23 \pm 0.2$ & $7.32 \pm 0.1$ & $*$ & $6.75 \pm 0.4$ \\
\hline \multirow{2}{*}{$\begin{array}{l}\text { Non-structural } \\
\text { polysaccharides^ }(\%)\end{array}$} & Con. & $50.77 \pm 0.1^{*}$ & $*$ & $53.98 \pm 0.05^{*}$ & $48.32 \pm 0.2^{*}$ & ns & $47.54 \pm 0.03^{*}$ \\
\hline & Germ. & $46.45 \pm 0.1$ & $*$ & $50.02 \pm 0.1$ & $47.31 \pm 0.3$ & ns & $47.46 \pm 0.04$ \\
\hline
\end{tabular}

Con: Control, Germ: Germinated.

*denotes the significant differences between control and germinated samples, ns: not significant Column ' $\mathbf{N}$ ' denotes the significant differences between organic and non-organic samples.

${ }^{\wedge}$ By difference as $100-($ moisture + protein + ash + fat+ dietary fiber $)$

Table 2 Mineral composition of chickpea and cowpea upon germination (mg/100g) (Dry weight basis)

\begin{tabular}{|c|c|c|c|c|c|c|c|}
\hline Parameter & Sample & $\begin{array}{l}\text { Organic } \\
\text { Chickpea } \\
\end{array}$ & $\mathbf{N}$ & $\begin{array}{l}\text { Non-organic } \\
\text { Chickpea }\end{array}$ & $\begin{array}{l}\text { Organic } \\
\text { Cowpea }\end{array}$ & $\mathbf{N}$ & $\begin{array}{l}\text { Non-organic } \\
\text { Cowpea }\end{array}$ \\
\hline \multirow{2}{*}{ Iron $(\mathrm{Fe})$} & Con. & $10.7 \pm 0.34^{*}$ & $*$ & $9.63 \pm 0.56^{*}$ & $9.32 \pm 0.65^{*}$ & $*$ & $11.62 \pm 0.33^{*}$ \\
\hline & Germ. & $7.82 \pm 0.14$ & $*$ & $6.76 \pm 0.01$ & $8.54 \pm 0.07$ & ns & $8.58 \pm 0.05$ \\
\hline \multirow{2}{*}{ Zinc (Zn) } & Con. & $5.86 \pm 0.4^{\mathrm{ns}}$ & ns & $5.53 \pm 0.22^{\mathrm{ns}}$ & $4.35 \pm 0.05^{\mathrm{ns}}$ & $*$ & $5.43 \pm 0.17^{*}$ \\
\hline & Germ. & $5.28 \pm 0.07$ & ns & $5.41 \pm 0.06$ & $4.21 \pm 0.1$ & $*$ & $4.71 \pm 0.04$ \\
\hline \multirow{2}{*}{ Calcium (Ca) } & Con. & $180.48 \pm 4.13^{*}$ & $*$ & $151.15 \pm 1.54^{*}$ & $76.08 \pm 2.78^{*}$ & $*$ & $96.19 \pm 0.95^{*}$ \\
\hline & Germ. & $101.8 \pm 4.5$ & $*$ & $97.6 \pm 1.1$ & $41.8 \pm 1.4$ & $*$ & $33.4 \pm 1.5$ \\
\hline \multirow{2}{*}{ Copper $(\mathrm{Cu})$} & Con. & $0.95 \pm 0.02^{*}$ & $*$ & $0.84 \pm 0.06^{*}$ & $0.41 \pm 0.02^{*}$ & $*$ & $0.49 \pm 0.03^{*}$ \\
\hline & Germ. & $1.0 \pm 0.0$ & $*$ & $1.22 \pm 0.0$ & $0.65 \pm 0.0$ & $*$ & $0.53 \pm 0.0$ \\
\hline \multirow{2}{*}{$\begin{array}{l}\text { Phosphorous } \\
\text { (P) }\end{array}$} & Con. & $244.9 \pm 1.5^{*}$ & $*$ & $239.02 \pm 1.44^{*}$ & $474.2 \pm 3.72^{*}$ & $*$ & $417.38 \pm 3.61^{*}$ \\
\hline & Germ. & $268.64 \pm 1.44$ & $*$ & $256.38 \pm 2.89$ & $481.61 \pm 0.72$ & $*$ & $469.19 \pm 0.72$ \\
\hline
\end{tabular}

The mineral content of the control and germinated org and n-org chickpea and cowpea are shown in Table 2. Iron content differed significantly between org and n-org chickpea and cowpea, and on germination, a significant decrease 
in the iron content of both the legumes was observed. Similar decreases in iron content after germination was seen in pigeon pea, black bean, and white beans [27]. Zinc content did not vary in the case of chickpea, whereas in the case of cowpea it varied between the org and n-org in control and germinated samples. Differences in calcium content between org and n-org chickpea and cowpea were observed. Germination significantly reduced the calcium content in both the legumes. When compared with earlier reports of Bains et al. [28] iron and zinc content were found to be higher, calcium content was similar. Reduction in the mineral constituents upon germination was observed, which is comparable with the earlier reports [28]. Copper content significantly differed between org and n-org chickpea and cowpea in control and germinated samples. A significant increase in copper content was observed after germination in both legumes, a similar increase in copper was observed in faba beans [29]. These control legume values are comparable to the literature values [25]. Phosphorous content of org legumes was found to be higher when compared with n-org, germination resulted in a significant increase in phosphorous content for both the legumes. This increase in the phosphorous content is due to the degradation of phytic acid by phytases during germination, similar results in black gram were observed by Reddy et al. [30]. Chickpea phosphorous values are comparable to the literature whereas cowpea was higher [23]. The mineral content variations between org and n-org chickpea and cowpea could be due to the differences in soil nutrition.

\subsection{Fatty acid profile}

Table 3 Fatty acid profile of chickpea and cowpea from organic and non-organic sources upon germination (\%)

\begin{tabular}{|l|l|l|l|l|l|l|l|}
\hline \multirow{2}{*}{ Fatty acid } & Sample & $\begin{array}{l}\text { Organic } \\
\text { Chickpea }\end{array}$ & $\mathbf{N}$ & $\begin{array}{l}\text { Non-organic } \\
\text { Chickpea }\end{array}$ & $\begin{array}{l}\text { Organic } \\
\text { Cowpea }\end{array}$ & N & $\begin{array}{l}\text { Non-organic } \\
\text { Cowpea }\end{array}$ \\
\hline \multirow{2}{*}{$\begin{array}{l}\text { Palmitic } \\
\text { acid(16:0) }\end{array}$} & Con. & $9.06 \pm 0.0^{\mathrm{ns}}$ & $*$ & $9.25 \pm 0.1^{\mathrm{ns}}$ & $27.25 \pm 0.4^{*}$ & $*$ & $24.33 \pm 0.9^{*}$ \\
\cline { 2 - 7 } & Germ. & $8.99 \pm 0.2$ & $\mathrm{~ns}$ & $9.12 \pm 0.2$ & $22.72 \pm 0.4$ & $*$ & $20.75 \pm 1.2$ \\
\hline \multirow{3}{*}{ Stearic acid(18:0) } & Con. & $0.40 \pm 0.0^{\mathrm{ns}}$ & $\mathrm{ns}$ & $0.39 \pm 0.0^{\mathrm{ns}}$ & $2.87 \pm 0.0^{*}$ & $*$ & $3.56 \pm 0.0^{*}$ \\
\cline { 2 - 7 } Oleic acid(18:1n9) & Germ. & $0.47 \pm 0.0$ & $*$ & $0.43 \pm 0.0$ & $2.98 \pm 0.0$ & $*$ & $3.71 \pm 0.0$ \\
\hline & Gon. & $22.86 \pm 0.3^{\mathrm{ns}}$ & $*$ & $24.77 \pm 0.7^{*}$ & $17.22 \pm 0.1^{*}$ & $*$ & $20.66 \pm 0.1^{*}$ \\
\hline \multirow{2}{*}{$\begin{array}{l}\text { Linoleic } \\
\text { acid(18:2n6) }\end{array}$} & Germ. & $22.59 \pm 1.7$ & $*$ & $25.87 \pm 0.4$ & $19.33 \pm 0.8$ & $*$ & $21.77 \pm 0.5$ \\
\hline \multirow{2}{*}{$\begin{array}{l}\alpha-L i n o l e n i c \\
\text { acid(18:3n3) }\end{array}$} & Germ. & $61.06 \pm 1.0^{\mathrm{ns}}$ & $\mathrm{ns}$ & $59.19 \pm 1.2^{\mathrm{ns}}$ & $33.09 \pm 1.0^{*}$ & $*$ & $31.3 \pm 1.0^{*}$ \\
\hline \multirow{2}{*}{ TSFA } & Con. & $1.69 \pm 0.0^{\mathrm{ns}}$ & $*$ & $1.61 \pm 0.0^{\mathrm{ns}}$ & $3.4 \pm 0.0^{*}$ & $*$ & $4.78 \pm 0.0^{*}$ \\
\cline { 2 - 8 } & Germ. & $1.71 \pm 0.0$ & $*$ & $1.62 \pm 0.0$ & $3.22 \pm 0.0$ & $*$ & $4.26 \pm 0.0$ \\
\hline \multirow{2}{*}{ TMUFA } & Con. & $9.46 \pm 0.0^{\mathrm{ns}}$ & $*$ & $9.64 \pm 0.0^{\mathrm{ns}}$ & $30.09 \pm 0.0^{*}$ & $*$ & $27.89 \pm 0.1^{*}$ \\
\cline { 2 - 8 } & Germ. & $9.46 \pm 0.0$ & $*$ & $9.68 \pm 0.0$ & $25.7 \pm 0.0$ & $*$ & $24.46 \pm 0.2$ \\
\hline \multirow{2}{*}{ TPUFA } & Con. & $22.86 \pm 0.3^{\mathrm{ns}}$ & $*$ & $24.77 \pm 0.7^{*}$ & $17.22 \pm 0.1^{*}$ & $*$ & $20.66 \pm 0.1^{*}$ \\
\cline { 2 - 8 } & Germ. & $22.59 \pm 1.7$ & $*$ & $25.87 \pm 0.4$ & $19.33 \pm 0.8$ & $*$ & $21.77 \pm 0.5$ \\
\hline
\end{tabular}

Con: Control, Germ: Germinated, TSFA: Total saturated fatty acids, TMUFA: Total monounsaturated fatty acids and TPUFA: Total polyunsaturated fatty acids.

*denotes the significant differences between control and germinated samples, ns: not significant.

Column 'N' denotes the significant differences between organic and non-organic samples.

Table 3. Represents the fatty acid profile of chickpea and cowpea. Significant differences in fatty acids between control org and n-org chickpea and cowpea were observed except for chickpea stearic acid and linoleic acid. Linoleic acid was the predominant fatty acid in chickpea (58.88-62.75\%) and cowpea (36.08-40.43\%). Reduction in the palmitic acid and $\alpha$-linoleic acid contents was observed upon germination in cowpea, whereas in chickpea significant change was not seen. Stearic acid, oleic acid, and linoleic acid contents increased upon germination in cowpea whereas in chickpea they did not vary significantly. The total saturated fatty acid (TSFA) content of n-org chickpea and org cowpea were higher when compared with their respective counterparts. While upon germination the TSFA content of org and n-org cowpea reduced significantly, in chickpea it was unchanged. Total monounsaturated fatty acid (TMUFA) content of n-org chickpea and org cowpea were higher when compared with their respective counterparts. Germination resulted in increased in TMUFA content in org and n-org cowpea, whereas in chickpea it was unchanged. No significant differences were observed in Total polyunsaturated fatty acid (TPUFA) content between org and n-org chickpea and cowpea. The TPUFA content significantly increased upon germination in org and n-org cowpea, whereas in chickpea it was unchanged. Germination for longer duration may increase the TMUFA and TPUFA content and reduce the TSFA, which 
are beneficial for human health. The literature results of control chickpea palmitic acid (10.87\%), stearic acid (1.85\%), oleic acid (33.51\%) and $\alpha$-linolenic acid (2.41\%) contents were slightly higher, whereas linoleic acid (49.74\%) content was lower when compared with the present study. TSFA (13.7\%) and MUFA (34.2\%) were higher and TPUFA (52.1\%) was lower than the current study [31]. Fatty acids are essential components of the body that help maintain a normal physiological function and a protective response to pathological stimuli [32]. Chickpea exhibits hypocholesterolemic effect due to its high content of essential fatty acids particularly linolenic and linoleic [26]. Oleic acid is a MUFA( $\omega-9)$ that is essential in human nutrition and helps to reduce levels of LDL-cholesterol, total cholesterol and glycemic index [33], and in the present study TMUFA in chickpea and cowpea exhibited significant qualities and germination of cowpea exhibited an increase in quantity which may be beneficial for human health.

\subsection{Enzyme activities}

Table 4 Enzyme activities of chickpea and cowpea upon germination

\begin{tabular}{|l|l|l|l|l|l|l|l|}
\hline $\begin{array}{l}\text { Enzyme } \\
\text { activity } \\
\text { (U/g) }\end{array}$ & Sample & $\begin{array}{l}\text { Organic } \\
\text { Chickpea }\end{array}$ & $\mathbf{N}$ & $\begin{array}{l}\text { Non- } \\
\text { organic } \\
\text { Chickpea }\end{array}$ & $\begin{array}{l}\text { Organic } \\
\text { Cowpea }\end{array}$ & N & $\begin{array}{l}\text { Non-organic } \\
\text { Cowpea }\end{array}$ \\
\hline \multirow{2}{*}{$\begin{array}{l}\text { Phytase } \\
\text { activity }\end{array}$} & Con. & $0.22 \pm 0.00^{*}$ & ns & $0.21 \pm 0.01^{*}$ & $0.34 \pm 0.01^{*}$ & ns & $0.33 \pm 0.02^{*}$ \\
\cline { 2 - 8 } & Germ. & $0.58 \pm 0.01$ & ns & $0.59 \pm 0.01$ & $0.71 \pm 0.00$ & ns & $0.69 \pm 0.02$ \\
\hline \multirow{2}{*}{$\begin{array}{l}\text { Amylase } \\
\text { activity }\end{array}$} & Con. & $6.2 \pm 0.50^{*}$ & ns & $6.5 \pm 0.30^{*}$ & $18.1 \pm 0.1^{*}$ & ns & $17.5 \pm 0.5^{*}$ \\
\cline { 2 - 8 } & Germ. & $22.1 \pm 1.0$ & ns & $20.5 \pm 0.8$ & $100.2 \pm 2.5$ & $*$ & $90.5 \pm 4.3$ \\
\hline $\begin{array}{l}\text { Protease } \\
\text { activity }\end{array}$ & Con. & $1.57 \pm 0.01^{*}$ & ns & $1.6 \pm 0.03^{*}$ & $0.90 \pm 0.0 *$ & ns & $0.92 \pm 0.01^{*}$ \\
\cline { 2 - 8 } & Germ. & $2.30 \pm 0.05$ & ns & $2.35 \pm 0.05$ & $2.6 \pm 0.15$ & ns & $2.75 \pm 0.09$ \\
\hline
\end{tabular}

Enzyme activities of the control and germinated legumes are presented in Table 4. The phytase activity of the germinated legumes was in the range of 0.21-0.71 U/g. Germination significantly increased phytase activity in both the legumes. No significant differences were observed between org and n-org chickpea or cowpea. An increase in the phytase activity after germination is beneficial in degrading the phytase content of the grains which may improve mineral bioavailability. Amylase activity of org and n-org chickpea and cowpea were similar except for germinated cowpea. Germination significantly increased the amylase activity of the legumes, cowpea exhibited the highest amylase activity when compared to chickpea. Protease activity significantly increased upon germination, and no significant differences were observed between org and n-org legumes. These results are in agreement with the earlier report of Ghavidel et al. [34].

\subsection{Anti-nutrients}

Anti-nutrient factors and molar ratios of minerals are presented in Table 5. Oxalic acid content was in the range of 7.22 to $14.28 \mathrm{mg} / 100 \mathrm{~g}$. Germination significantly increased the oxalic acid content. These results of control n-org chickpea and cowpea oxalic acid were comparable with the total oxalic acid of an earlier report of Longvah et al. [25]. A similar increase in oxalic acid during the germination of wheat was reported by Steve [35]. PA content of org chickpea found to be significantly lower than the n-org, whereas no significant differences were observed in the case of cowpea. Germination significantly reduced the PA content of both the legumes. El-Adawy [36] and Ibrahim et al. [5] observed a similar decrease in phytic acid content upon germination. The saponin content of control org legumes was found to be significantly lower than n-org grown. Germination significantly decreased the saponin content of legumes. A similar reduction in saponin content in chickpea upon germination was observed by El-Adawy [36]. The decrease in phytic acid improves mineral bioavailability and reduction in saponins decreases the off-taste and hemolytic property. The molar ratios of PA with minerals exhibited significant differences between org and n-org chickpea and cowpea except in the case of PA:Ca:Zn for cowpea. Germination brought a significant reduction in PA because of increased activity of phytase, this resulted in the reduction of the molar ratios of PA:Fe, PA:Zn of org and n-org chickpea (8.45,10.24 to 5.51,7.25; $18.09,20.96$ to $9.57,10.62$ respectively) and cowpea $(11.97,10.91$ to $9.31,8.08 ; 30.07,27.37$ to $22.12,17.25$ respectively). The PA:Ca ratio of the chickpea reduced significantly upon germination but whereas in cowpea it increased. The PA:Ca:Zn ratio is the better indicator of zinc bioavailability molar ratios above $50 \mathrm{mM} / 100 \mathrm{~g}$ dry diet may be of concern for poor zinc status [37]. Zinc availability upon germination is improved for chickpea, though in case of cowpea it decreased, this may be due to the significant loss in calcium upon germination of cowpea. Overall the bioavailability of 
minerals improved significantly upon germination except for cowpea PA:Ca:Zn. Germination for longer durations may reduce the phytic acid content furthermore and increase the availability of minerals.

Table 5 Effect of growing conditions and germination on antinutrients of chickpea and cowpea

\begin{tabular}{|c|c|c|c|c|c|c|c|}
\hline Antinutrient & Sample & $\begin{array}{l}\text { Organic } \\
\text { Chickpea }\end{array}$ & $\mathbf{N}$ & $\begin{array}{l}\text { Non-organic } \\
\text { Chickpea }\end{array}$ & $\begin{array}{l}\text { Organic } \\
\text { Cowpea }\end{array}$ & $\mathbf{N}$ & $\begin{array}{l}\text { Non- } \\
\text { organic } \\
\text { Cowpea }\end{array}$ \\
\hline \multirow{2}{*}{$\begin{array}{ll}\text { Oxalic } & \text { acid } \\
\mathrm{mg} / 100 \mathrm{~g} & \end{array}$} & Con. & $7.22 \pm 0.24 *$ & ns & $7.41 \pm 0.43^{*}$ & $13.73 \pm 1.43^{\mathrm{ns}}$ & ns & $13.24 \pm 0.24^{\mathrm{ns}}$ \\
\hline & Germ. & $8.28 \pm 0.19$ & ns & $8.26 \pm 0.24$ & $14.28 \pm 1.19$ & ns & $13.58 \pm 1.19$ \\
\hline \multirow{2}{*}{ Phytic acid g/100g } & Con. & $1.07 \pm 0.07^{*}$ & $*$ & $1.17 \pm 0.05^{*}$ & $1.32 \pm 0.21^{*}$ & ns & $1.5 \pm 0.19 *$ \\
\hline & Germ. & $0.51 \pm 0.09$ & $*$ & $0.58 \pm 0.02$ & $0.94 \pm 0.08$ & * & $0.82 \pm 0.00$ \\
\hline \multirow{2}{*}{$\begin{array}{l}\text { Saponins } \\
\mathrm{mg} / 100 \mathrm{~g}\end{array}$} & Con. & $68.23 \pm 4.29 *$ & $*$ & $78.63 \pm 3.02 *$ & $338.5 \pm 6.18^{*}$ & $*$ & $472.2 \pm 5.36^{*}$ \\
\hline & Germ. & $52.11 \pm 1.46$ & $*$ & $61.26 \pm 2.32$ & $201.8 \pm 9.65$ & $*$ & $213.7 \pm 5.06$ \\
\hline \multicolumn{8}{|c|}{ Phytic acid (PA) and mineral ratios } \\
\hline \multirow{2}{*}{ PA:Fe } & Con. & 8.45 & - & 10.27 & 11.97 & - & 10.91 \\
\hline & Germ. & 5.51 & - & 7.25 & 9.31 & - & 8.08 \\
\hline \multirow{2}{*}{$\mathrm{PA}: \mathrm{Zn}$} & Con. & 18.09 & - & 20.96 & 30.07 & - & 27.37 \\
\hline & Germ. & 9.57 & - & 10.62 & 22.12 & - & 17.25 \\
\hline \multirow{2}{*}{ PA:Ca } & Con. & 0.36 & - & 0.47 & 1.05 & - & 0.95 \\
\hline & Germ. & 0.30 & - & 0.36 & 1.36 & - & 1.49 \\
\hline \multirow{2}{*}{ PA:Ca:Zn } & Con. & 19.86 & - & 22.38 & 34.97 & - & 34.53 \\
\hline & Germ. & 31.72 & - & 33.9 & 61.6 & - & 86.25 \\
\hline
\end{tabular}

\section{Conclusion}

Org and n-org legumes showed significant differences in the nutrient composition of chickpea and cowpea except in the case of protein for chickpea and NSP content in cowpea. Germination brought significant changes in macronutrient content, except fat and IDF of chickpea and ash and the fiber content of the cowpea. A significant increase in soluble fiber content was observed in both the legumes which are beneficial for human health. Org chickpea exhibited significantly higher mineral content when compared with n-org chickpea, whereas n-org cowpea exhibited higher mineral content, except for phosphorous. Germination significantly reduced the mineral content except for copper and phosphorous. The fatty acid content of org and n-org chickpea and cowpea varied significantly except for stearic, linoleic acid of chickpea, and TMUFA of both legumes. Germination increased TMUFA and TPUFA contents in the cowpea which promotes the lowering of LDL cholesterol and glycemic index. Enzyme activities did not show greater differences between the org and n-org, whereas upon germination their activity significantly increased. Anti-nutrient factors were greatly affected by germination, a significant reduction in phytic acid and saponin content was observed whereas oxalic acid content increased. The molar ratios of PA:Fe, PA:Ca, and PA:Zn reduced significantly upon germination and may promote better availability of minerals. Growing conditions and germination influenced the nutritional and nutritional factors of legumes, but no particular trend was seen to prove that org legumes are better in nutritional quality than norg legumes.

\section{Compliance with ethical standards}

\section{Acknowledgments}

The authors would like to acknowledge DST-PURSE Phase-II (New Delhi, India), awarded to University of Mysore for providing the financial and infrastructural facilities required to carry out this work. 


\section{Disclosure of conflict of interest}

The authors declare that there is no conflict of interest.

\section{References}

[1] Khatoon N, Prakash J. Cooking quality and sensory profile of microwave and pressure cooked legumes. Indian Journal of Nutrition and Dietetics. 2005; 42:13-21.

[2] Sharma S, Saxena AK, Bakshi AK, Brar JS. Evaluation of different mungbean (vigna radiata) genotypes for physicochemical and cooking quality characteristics. Indian Journal of Nutrition and Dietetics. 2007; 44:197-202.

[3] Sood M, Malhotra SR, Sood BC. Effect of processing and cooking on proximate composition of chickpea (Cicer arietinum) varieties. Journal of Food Science and Technology. 2002; 39:69-71.

[4] Alajaji SA, El-Adawy TA. Nutritional composition of chickpea (Cicer arietinum L.) as affected by microwave cooking and other traditional cooking methods. Journal of Food Composition and Analysis. 2006; 19:806-12.

[5] Ibrahim SS, Habiba RA, Shatta AA, Embaby HE. Effect of soaking, germination, cooking and fermentation on antinutritional factors in cowpeas. Food/Nahrung, 2002; 46:92-95.

[6] Sreerama YN, Sashikala VB, Pratape VM, Singh V. Nutrients and antinutrients in cowpea and horse gram flours in comparison to chickpea flour: Evaluation of their flour functionality. Food Chemistry. 2012; 131:462-68.

[7] Korcak RF. Early roots of the organic movement: A plant nutrition perspective. Hort Technology. 1992; 2:26367.

[8] Röhlig RM, Engel KH. Influence of the input system (conventional versus organic farming) on metabolite profiles of maize (Zea mays) kernels. Journal of Agricultural and Food Chemistry. 2010; 58:3022-30.

[9] Malleshi NG, Klopfenstein CF. Proximate composition, amino acid and vitamin contents of malted chickpea, mungbean and their seed coats. Journal of Food Science and Technology. 1996; 33:479-82.

[10] Savelkoul FHMG, Van der Poel AFB, Tamminga S. The presence and inactivation of trypsin inhibitors, tannins, lectins and amylase inhibitors in legume seeds during germination. A review. Plant Foods for Human Nutrition,. 1992; 42:71-85.

[11] AOAC. Official Methods of Analysis. 16th edn, Association of Official Analytical Chemists, Washington DC. 2002.

[12] Asp NG, Johansson CG, Hallmer H, Siljestroem M. Rapid enzymic assay of insoluble and soluble dietary fiber. Journal of Agricultural and Food Chemistry. 1983; 31:476-82.

[13] Patil MM, Muhammed AM, Anu-Appaiah KA. Lipids and fatty acid profiling of major Indian Garcinia Fruit: A comparative study and its nutritional impact. Journal of the American Oil Chemists Society. 2016; 93:823-36.

[14] Egli I, Davidsson L, Juillerat MA, Barclay D, Hurrell RF. The influence of soaking and germination on the phytase activity and phytic acid content of grains and seeds potentially useful for complementary feeding. Journal of Food Science. 2002; 67:3484-88.

[15] Fiske CH, Subbarow Y. The colorimetric determination of phosphorus. Journal of Biological Chemistry. 1925; 66:375-400.

[16] Bernfeld P. $\alpha$-and $\beta$-amylases. Methods in Enzymology. 1955; 1:149-58.

[17] Müntz K. Proteases and proteolytic cleavage of storage proteins in developing and germinating dicotyledonous seeds. Journal of Experimental Botany. 1996; 47:605-622.

[18] Haug W, Lantzsch HJ. Sensitive method for the rapid determination of phytate in cereals and cereal products. Journal of the Science of Food and Agriculture. 1983; 34:1423-26.

[19] Hiai S, Oura H, Nakajima T. Color reaction of some sapogenins and saponins with vanillin and sulfuric acid. Planta Medica, 1976; 29:116-22.

[20] Agbaire PO, Emoyan 00. Nutritional and antinutritional levels of some local vegetables from Delta State, Nigeria. African Journal of Food Science. 2012; 6:8-11.

[21] Uppal V, Bains K. Effect of germination periods and hydrothermal treatments on in vitro protein and starch digestibility of germinated legumes. Journal of Food Science and Technology. 2012; 49:184-91. 
[22] Sreerama YN, Sasikala VB, Pratape VM. Nutritional implications and flour functionality of popped/expanded horse gram. Food Chemistry. 2008; 108:891-99.

[23] Iqbal A, Khalil IA, Ateeq N, Khan MS. Nutritional quality of important food legumes. Food Chemistry. 2006; 97:331-35.

[24] Delzenne NM, Olivares M, Neyrinck AM, Beaumont M, Kjølbæk L, Larsen TM, Sanz Y. Nutritional interest of dietary fiber and prebiotics in obesity: Lessons from the MyNewGut consortium. Clinical Nutrition. 2020; 39:414-24.

[25] Longvah T, Anantan I, Bhaskarachary K, Venkaiah K. Indian food composition tables. Indian Council of Medical Research:National Institute of Nutrition, Hyderabad. 2017.

[26] Singh U. Nutritional quality of chickpea (Cicer arietinum L.): current status and future research needs. Plant Foods for Human Nutrition. 1985; 35:339-51.

[27] Sangronis E, Machado CJ. Influence of germination on the nutritional quality of Phaseolus vulgaris and Cajanus cajan. LWT-Food Science and Technology. 2007; 40:116-20.

[28] Bains K, Uppal V, Kaur H. Optimization of germination time and heat treatments for enhanced availability of minerals from leguminous sprouts. Journal of Food Science and Technology. 2014; 51:1016-20.

[29] Youssef MM, El-Aal MA, Shekib LA, Ziena HM. Effects of dehulling, soaking and germination on chemical composition, mineral elements and protein patterns of faba beans (Vicia faba L.). Food Chemistry. 1987; 23:12938.

[30] Reddy NR, Balakrishnan CV, Salunkhe DK. Phytate phosphorus and mineral changes during germination and cooking of black gram (Phaseolus mungo) seeds. Journal of Food Science. 1978; 43:540-43.

[31] Ryan E, Galvin K, O'Connor TP, Maguire AR, O'Brien NM. Phytosterol, squalene, tocopherol content and fatty acid profile of selected seeds, grains, and legumes. Plant Foods for Human Nutrition. 2007; 62:85-91.

[32] McClelland JW. Handbook of Lipids in Human Function. Journal of Nutrition Education and Behavior. 2016; 48:595.

[33] Rubio M, Alvarez-Orti M, Alvarruiz A, Fernandez E, Pardo JE. Characterization of oil obtained from grape seeds collected during berry development. Journal of Agricultural and Food Chemistry. 2009; 57:2812-15.

[34] Ghavidel RA, J Prakash J, MG Davoodi MG. Assessment of enzymatic changes in some legume seeds during germination. Agro Food Industry Hi-Tec. 2011; 22:45-47.

[35] Steve IO. Influence of germination and fermentation on chemical composition, protein quality and physical properties of wheat flour (Triticum aestivum). Journal of Cereals and Oil seeds. 2012; 3:35-47.

[36] El-Adawy TA. Nutritional composition and antinutritional factors of chickpeas (Cicer arietinum L.) undergoing different cooking methods and germination. Plant Foods for Human Nutrition. 2002; 57:83-97.

[37] Fordyce EJ, Forbes RM, Robbins KR, Erdman JW. Phytatex calcium/zinc molar ratios: are they predictive of zinc bioavailability? Journal of Food Science. 1987; 52:440-44. 